\title{
Rabbit Papilloma
}

National Cancer Institute

\section{Source}

National Cancer Institute. Rabbit Papilloma. NCI Thesaurus. Code C134998.

A rabbit papilloma that is associated with infection by the Shope papilloma virus. 